\title{
FORMATION AND INFLUENCE OF MAGNESIUM-ALUMINA SPINEL ON THE PROPERTIES OF REFRACTORY FORSTERITE-SPINEL CERAMICS
}

\author{
TVORBA IN VPLIV MAGNEZIT-ALUMINATNEGA ŠPINELA NA \\ LASTNOSTI OGNJEVARNE FORSTERIT-ŠPINELNE KERAMIKE
}

\author{
Martin Nguyen*, Radomír Sokolár \\ Brno University of Technology, Faculty of Civil Engineering, Institute of Technology of Building Materials and Components, \\ Veveř́ 331/95, 60200 Brno, Czech Republic
}

Prejem rokopisa - received: 2019-08-21; sprejem za objavo - accepted for publication: 2019-11-04

doi:10.17222/mit.2019.198

Forsterite refractory ceramic is mostly used in the cement industry as the lining of a rotary kiln and as the lining of metallurgical furnaces due to its high refractoriness of up to $1850{ }^{\circ} \mathrm{C}$. Another significant property of forsterite is its coefficient of linear thermal expansion used in the electrotechnical industry for ceramic-metal joints. An addition of aluminium oxide to a raw-material mixture results in the creation of a magnesium-alumina spinel $\left(\mathrm{MgO} \cdot \mathrm{Al}_{2} \mathrm{O}_{3}\right)$, which improves the sintering and mechanical properties of forsterite ceramics. An inexpensive source of aluminium oxide is fly ash. The utilization of fly ash, a secondary energy product of coal-burning power plants, is important for the environment and sustainable development. This paper evaluates the transformation of mullite $\left(3 \mathrm{Al}_{2} \mathrm{O}_{3} \cdot 2 \mathrm{SiO}_{2}\right)$ from fly ash into a magnesium-alumina spinel, its influence during the synthesis and the resulting properties of a fired forsterite refractory ceramic body. Forsterite-spinel ceramics were synthesized from olivine, calcined magnesite and 0-20\% of fly-ash powders. XRD analyses were used to determine the mineralogical composition, thermal analyses were used to determine the formation of spinel and its behaviour during the firing, and scanning electron microscopy (SEM) was used to determine the morphology of crystal phases. The refractoriness of pyrometric cones, refractoriness under load, thermal-shock resistance, water absorption, porosity and mechanical properties of the fired test samples were also determined. The transformation of mullite resulted in small amounts of magnesium-alumina spinel in the forsterite ceramics. Test results showed that the presence of magnesium-alumina spinel improved the sintering, microstructure, thermal-shock resistance and mechanical properties in comparison with pure-forsterite refractory ceramics.

Keywords: forsterite, magnesium-alumina spinel, refractory, fly ash

Forsteritna ognjevarna keramika se najbolj pogosto uporablja v industriji cementa kot obzidava za rotacijske peči in kot notranja obzidava metalurških peči zaradi njene odlične termične stabilnosti pri visokih temperaturah, vse do $1850^{\circ} \mathrm{C}$. Druga pomembna lastnost forsterita je njegov koeficient linearnega toplotnega raztezanja zaradi česar se uporablja tudi v elektrotehniški industriji za izdelavo spojev keramika-kovina. Na koncu je rezultat dodajanja aluminijevega oksida, kot osnovne surovine v mešanici, nastanek magnezitno-aluminatnega špinela $\left(\mathrm{MgO} \cdot \mathrm{Al}_{2} \mathrm{O}_{3}\right)$, ki izboljša potek sintranja in mehanske lastnosti forsteritne keramike. Cenen vir aluminijevega oksida je dimniški pepel. Uporaba dimniškega pepela, ki je sekundarni produkt termoelektrarn na premog, je pomembna $\mathrm{z}$ ekološkega vidika in trajnostnega razvoja. V članku avtorji opisujejo oceno pretvorbe mulita $\left(3 \mathrm{Al}_{2} \mathrm{O}_{3} \cdot 2 \mathrm{SiO}_{2}\right)$, ki ga vsebuje dimniški pepel, v magnezitno-aluminatni špinel in njen vpliv na sintezo, kakor tudi na lastnosti žgane na osnovi forsterita nastale ognjevarne keramične opeke. Forsteritno-špinelno keramiko so sintetizirali iz olivina, kalciniranega magnezita in dodatka $0 \%$ do $20 \%$ prahu dimniškega pepela. Za določitev mineraloške sestave so uporabili rentgensko difrakcijsko analizo (XRD), termično analizo (TGA) pa so uporabili za določitev tvorbe špinela in obnašanja med procesom žganja. Morfologijo kristalnih faz so določili z vrstičnim elektronskim mikroskopom (SEM). Na žganih stožcih iz izdelane keramike, so določili njeno ognjevarnost, na drugih preizkušancih pa še njeno odpornost pod obremenitvami ter odpornost proti termičnim šokom, absorpcijo vode, poroznost in mehanske lastnosti. Rezultat pretvorbe mulita je bila majhna vsebnost magnezitno-aluminatnega špinela v forsteritni keramiki. Rezultati preizkusov so še pokazali, da prisotnost magnezitno-aluminatnega špinela izboljša sintranje, mikrostrukturo, odpornost proti termo šokom in mehanske lastnosti $v$ primerjavi s čisto forsteritno ognjevarno keramiko.

Ključne besede: forsterit, magnezitno-aluminatni špinel, ognjevarnost, dimniški pepel

\section{INTRODUCTION}

Forsterite is magnesium silicate with the chemical formula $2 \mathrm{MgO} \cdot \mathrm{SiO}_{2}$. The melting point of forsterite is $1890{ }^{\circ} \mathrm{C}$, which makes it very useful for refractory ceramics. ${ }^{1}$ Forsterite is used in the industry as the lining of the sintering zone of rotary kilns and metallurgical furnaces..$^{2-3}$ Another significant attribute of forsterite ceramics is a high coefficient of linear thermal expan-

*Corresponding author's e-mail:

nguyen.m@fce.vutbr.cz (Martin Nguyen) sion, which is similar to the coefficients of metals. For this reason, forsterite is used in electrical engineering for joining ceramics with metals. ${ }^{4}$

Because of a high coefficient of linear thermal expansion, forsterite has a low thermal-shock resistance. This attribute can be improved through an addition of aluminium oxide, creating a magnesium-aluminate (MA) spinel. With the addition of spinel to a forsterite ceramic, the microstructure is improved, leading to higher mechanical properties. ${ }^{5}$ 
Traditionally, spinel ceramics are sintered from alumina and magnesium oxides. ${ }^{6}$ However, fly ash as a secondary product from power plants can also be a source of aluminium and silicon oxides that can be utilized as raw materials for sintering forsterite-spinel ceramics. ${ }^{7-11}$ The formation of MA spinel from the mixtures with fly ash also occurred in our previous work. ${ }^{12-13}$ The main objective of this work is the clarification of the formation and influence of an MA spinel on the resulting properties of forsterite ceramics. Thermal analyses, microstructure, phase composition, physico-mechanical properties and refractory properties are investigated and compared with the forsterite ceramics without MA spinels.

\section{EXPERIMENTAL PART}

Three different raw-material mixtures were designed for the synthesis of forsterite refractory ceramics. Raw materials used for the synthesis of these mixtures were olivine (A/S Olivin, Norway), calcined caustic magnesite (CCM 85, min. $85 \%$ of MgO, SMZ, a.s. Jelšava, Slovakia), fly ash (power plant Mělník, Czech Republic) and kaolin Sedlec Ia (Sedlecký kaolin a.s., Czech Republic). Designation of individual mixtures was based on the fly-ash content of the concerned mixture. Mixture OCF-0 had $0.0 \%$ of fly ash, OCF-10 had $10.0 \%$ of fly ash and OCF-20 had $20.0 \%$ of fly ash. Compositions of all raw-material mixtures are presented in Table 1. Chemical compositions of the used raw materials were determined using a chemical analysis and they are presented in Table 2.
Table 1: Designed compositions of all raw-material mixtures

\begin{tabular}{|c|c|c|c|}
\hline Raw materials & $\begin{array}{c}\text { OCF-0 } \\
(w / \%)\end{array}$ & $\begin{array}{c}\text { OCF-10 } \\
(w / \%)\end{array}$ & $\begin{array}{c}\text { OCF-20 } \\
(w / \%)\end{array}$ \\
\hline CCM 85 & 40.3 & 43.2 & 44.1 \\
\hline Olivine & 54.7 & 41.8 & 30.9 \\
\hline Fly ash Mělník & 0.0 & 10.0 & 20.0 \\
\hline Kaolin Sedlec Ia & 5.0 & 5.0 & 5.0 \\
\hline
\end{tabular}

X-ray diffraction analysis (XRD) of the used raw materials is presented in Figure 1. The major crystal phase in CCM 85 (calcined caustic magnesite) is periclase and the minor phase is magnetite. The major crystal phases in olivine are forsterite and fayalite with minor traces of quartz and serpentine. The crystal phases in fly ash Mělník are mullite and quartz. The curved background of diffraction patterns also indicates the presence of an amorphous glass phase and iron oxide. The major crystal phases in kaolin Sedlec Ia are kaolinite and the minor phase is biotite.

Test samples were prepared from all designed mixtures and were subjected to homogenization in a rotary mechanical homogenizer for 24 hours to ensure homogeneity. The mixtures were then mixed with water to gain the optimal viscosity of plastic paste for the plastic moulding of the test samples. Approximate dimensions of the test samples were $(20 \times 25 \times 100)$ $\mathrm{mm}^{3}$. Pyrometric cones for the refractoriness test were also prepared from the same plastic paste according to the official standard EN 993-13:1995. Green bodies were then dried in the laboratory dryer at $105^{\circ} \mathrm{C}$. All the test samples were then fired in an electrical laboratory furnace with air atmosphere at two different firing temperatures of $1400{ }^{\circ} \mathrm{C}$ and $1500{ }^{\circ} \mathrm{C}$, with a heating rate of

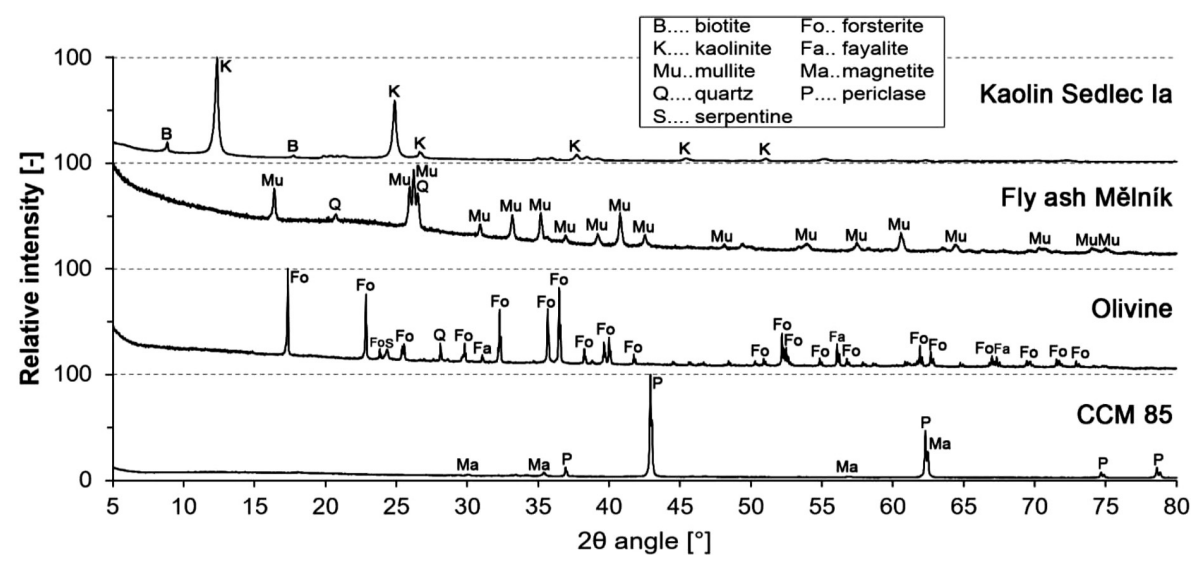

Figure 1: XRD of the used raw materials without heat treatment

Table 2: Chemical compositions of used raw materials

\begin{tabular}{|c|c|c|c|c|c|c|c|}
\hline Raw materials & $\begin{array}{c}\mathrm{MgO} \\
(\%)\end{array}$ & $\begin{array}{c}\mathrm{SiO}_{2} \\
(\%)\end{array}$ & $\begin{array}{c}\mathrm{CaO} \\
(\%)\end{array}$ & $\begin{array}{c}\mathrm{Fe}_{2} \mathrm{O}_{3} \\
(\%)\end{array}$ & $\begin{array}{c}\mathrm{Al}_{2} \mathrm{O}_{3} \\
(\%)\end{array}$ & $\begin{array}{c}\mathrm{K}_{2} \mathrm{O}_{2}+\mathrm{Na}_{2} \mathrm{O} \\
(\%)\end{array}$ & $\begin{array}{c}\mathrm{LOI}^{*} \\
(\%)\end{array}$ \\
\hline CCM 85 & 85.0 & 0.5 & 5.2 & 7.3 & 0.8 & 0.2 & 1.0 \\
\hline Olivine & 24.1 & 64.7 & 0.7 & 8.8 & 1.0 & 0.5 & 1.0 \\
\hline Fly ash Mělník & 1.4 & 57.3 & 2.2 & 5.1 & 29.3 & 1.7 & 1.2 \\
\hline Kaolin Sedlec Ia & 0.5 & 46.8 & 0.7 & 0.9 & 36.6 & 1.2 & 13.2 \\
\hline
\end{tabular}

*Loss on ignition 
Table 3: Test results for the fired samples

\begin{tabular}{|l|c|c|c|c|c|c|}
\hline \multicolumn{1}{|c|}{ Test samples } & OCF-0-1400 & OCF-10-1400 & OCF-20-1400 & OCF-0-1500 & OCF-10-1500 & OCF-20-1500 \\
\hline Fly ash amount $(w / \%)$ & 0.0 & 10.0 & 20.0 & 0.0 & 10.0 & 20.0 \\
\hline Firing temperature $\left({ }^{\circ} \mathrm{C}\right)$ & 1400 & 1400 & 1400 & 1500 & 1500 & 1500 \\
\hline Firing shrinkage $(\%)$ & 3.4 & 4.1 & 3.2 & 5.7 & 7.2 & 7.5 \\
\hline Apparent porosity $(\%)$ & 32.7 & 36.1 & 41.2 & 27.0 & 31.1 & 35.2 \\
\hline Water absorption $(\%)$ & 14.4 & 16.7 & 20.7 & 10.9 & 13.3 & 16.1 \\
\hline Bulk density $\left(\mathrm{kg} \cdot \mathrm{m}^{-3}\right)$ & 2280 & 2160 & 1990 & 2470 & 2340 & 2190 \\
\hline Modulus of rupture $(\mathrm{MPa})$ & 9.1 & 10.0 & 11.6 & 11.4 & 13.5 & 17.4 \\
\hline Residual modulus of rupture $(\%)$ & 2.7 & 14.9 & 19.9 & 3.5 & 23.0 & 30.5 \\
\hline Refractoriness $\left({ }^{\circ} \mathrm{C}\right)$ & 1726 & 1692 & 1665 & 1730 & 1693 & 1667 \\
\hline
\end{tabular}

$4{ }^{\circ} \mathrm{C} / \mathrm{min}$ and soaking time of $120 \mathrm{~min}$ at the maximum temperature.

Several experimental procedures were performed on the test samples after the firing. The apparent porosity, water absorption and bulk density were determined utilizing the vacuum water-absorption method described in the official standard EN 993-1:1995. Thermal analyses DTA/TG and DSC of all the mixtures (ČSN 72 1083) were carried out. A change in a dimension (length) of the test samples was noticed during the firing (EN 99310:1997). Other observations included: the refractoriness of the pyrometric cones (EN 993-12:1997), refractoriness under load (ISO 1893:2007) and thermal-shock resistance (EN 993-11:2007). A thermal dilatometric analysis (EN 993-19:2004) was carried out. The modulus of rupture was tested using a Testometric M350-20CT (EN 993-6:1995).

The mineralogical compositions of the fired test samples were identified using the X-ray diffraction analysis (XRD; PANALYTICAL Empyrean) with $\mathrm{Cu}-\mathrm{K} \alpha$ as the radiation source, an accelerating voltage of $45 \mathrm{kV}$, a beam current of $40 \mathrm{~mA}$, a diffraction angle of $2 \theta$ in a range of $5-80^{\circ}$ with a step scan of $0,01^{\circ}$. Scanning electron microscopy (SEM) with an EDX probe (Tescan MIRA3) was used to determine the morphology and elemental analysis of the crystal structure.

\section{RESULTS}

The creation and influence of the MA spinel in forsterite ceramics are studied in this paper to understand the process of recrystallization of aluminium oxide bearing minerals to the MA spinel. The XRD analysis

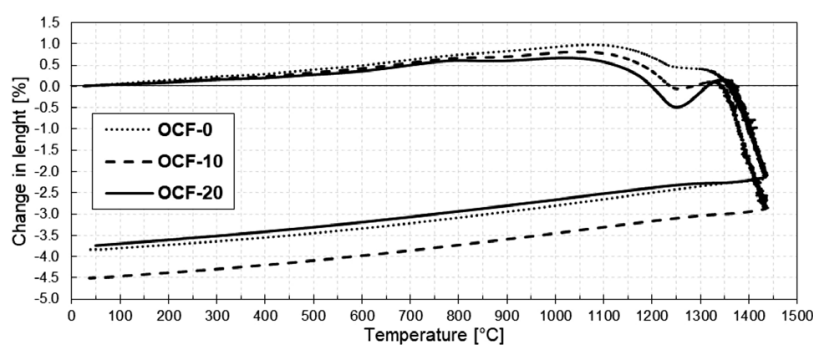

Figure 2: Thermal dilatometric analysis of the mixtures with different amounts of fly ash presented in Figure 1 confirmed the presence of kaolinite $\left(\mathrm{Al}_{2} \mathrm{O}_{3} \cdot 2 \mathrm{SiO}_{2} \cdot 2 \mathrm{H}_{2} \mathrm{O}\right)$ in kaolin Sedlec Ia and mullite $\left(3 \mathrm{Al}_{2} \mathrm{O}_{3} \cdot 2 \mathrm{SiO}_{2}\right)$ in fly ash Mělník as the sources of $\mathrm{Al}_{2} \mathrm{O}_{3}$. In the presence of magnesium oxide, they formed the MA spinel $\left(\mathrm{MgO} \cdot \mathrm{Al}_{2} \mathrm{O}_{3}\right)$. This phenomenon is supported by the XRD analysis and SEM with the EDX probe used on the fired samples containing fly ash and kaolin as reported in the reference literature. ${ }^{8}$

Residual MOR is the quantity of the thermal-shock resistance of the test samples, heated to $950{ }^{\circ} \mathrm{C}$ and then quickly cooled down with air while this cycle is repeated 4 times. After all the cycles, the MOR of the tested samples is measured and compared with the MOR of the non-tested samples. Refractoriness is decreased for the samples with a higher amount of fly ash due to a higher amount of flux oxides such as $\mathrm{Fe}_{2} \mathrm{O}_{3}, \mathrm{Na}_{2} \mathrm{O}$ and $\mathrm{K}_{2} \mathrm{O}$; however, the decrease is less than $5 \%$.

Figure 2 displays the behaviour during the sintering of all the samples with a varying amount of fly ash $(0,10$ and 20) $\%$. The sintering process can be divided into three stages. The first stage is the shrinkage at $1100-1250{ }^{\circ} \mathrm{C}$, the second stage is the expansion at $1250-1350{ }^{\circ} \mathrm{C}$ and the third stage is re-shrinkage $\left(>1350{ }^{\circ} \mathrm{C}\right)$.

Figure 3 displays the determination of refractoriness under load of the fired samples. With the increasing amount of fly ash in the mixture, the temperature at $0.5 \%$ deformation $\left(T_{0.5}\right)$ is decreasing due to the increased amount of flux oxides; however, the decrease is less than $3 \%$.

The microstructure of the test samples was evaluated using SEM with an EDX probe. Mixture OCF-0 without fly ash had large forsterite crystals interlocked into the

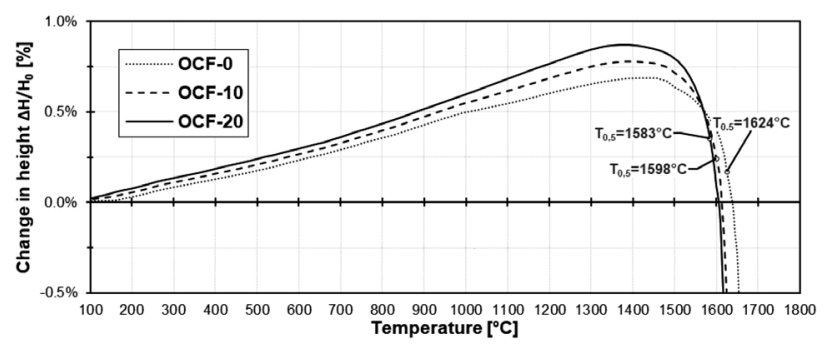

Figure 3: Determination of refractoriness under load of the mixtures with different amounts of fly ash 

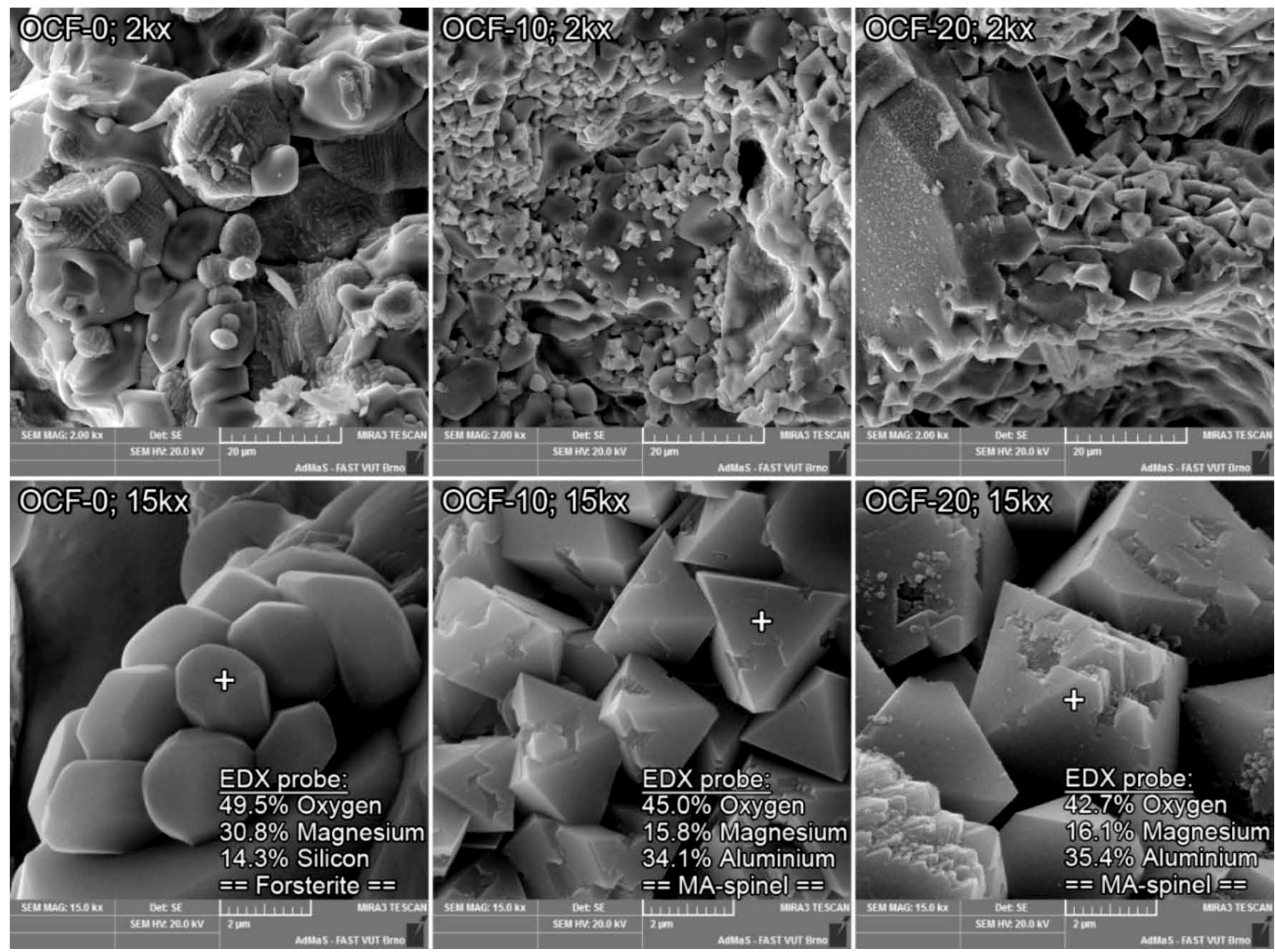

Figure 4: SEM of different mixtures with magnifications of $2000 \times$ (top) and $15000 \times$ (bottom)

matrix with few periclase crystals. On the left bottom image there is a rounded patch of forsterite crystals. Mixtures OCF-10 and OCF-20 with fly ash also contained orthorhombic dipyramidal crystals of the MA spinel (bottom middle and right images), located in the patches between the forsterite crystals and in the space between them, creating a more compact microstructure.

The XRD analysis confirmed the presence of forsterite in all the mixtures. Mixture OCF-0 (without fly ash) had a major crystal phase of forsterite and minor phases of periclase, magnetite and monticellite. Mixture OCF-10 and OCF-20 (with $10 \%$ and $20 \%$ of fly ash, respectively) had a major crystal phase of forsterite and minor phases of periclase, MA spinel and monticellite.

The thermal analyses (Figures 6 to 8) performed on the test samples were DTA/TG and DSC using a Mettler Toledo TGA/DSC1 device up to $1350{ }^{\circ} \mathrm{C}$ at a heating rate of $10^{\circ} \mathrm{C} / \mathrm{min}$.

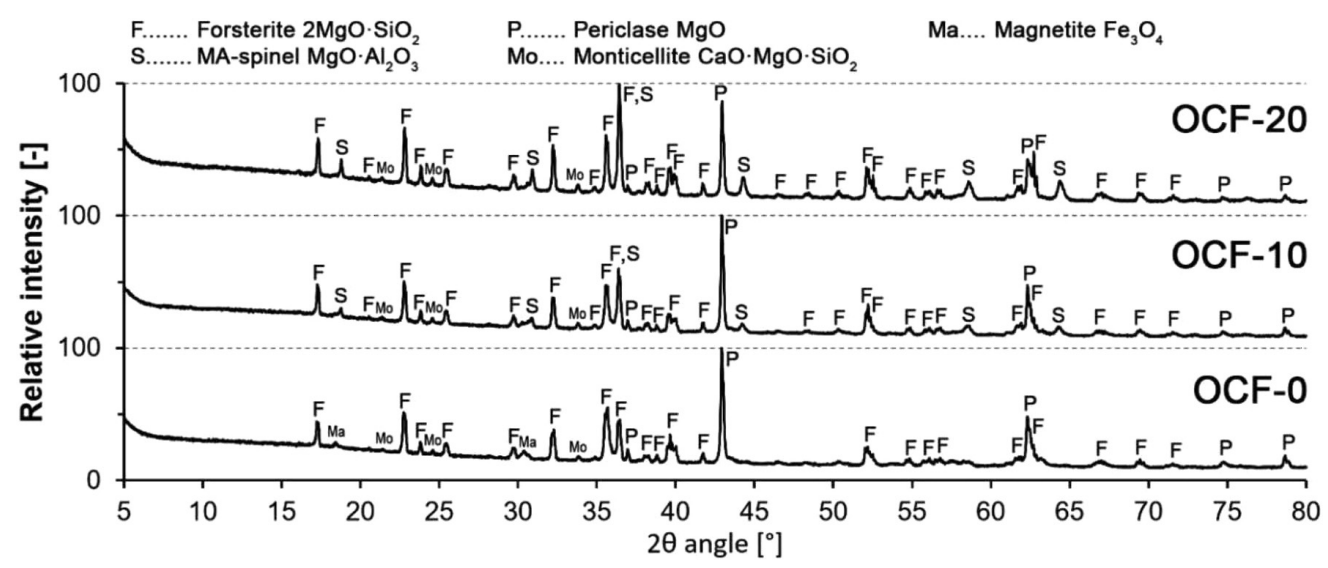

Figure 5: X-ray diffraction patterns of all the mixtures with different amounts of fly ash 


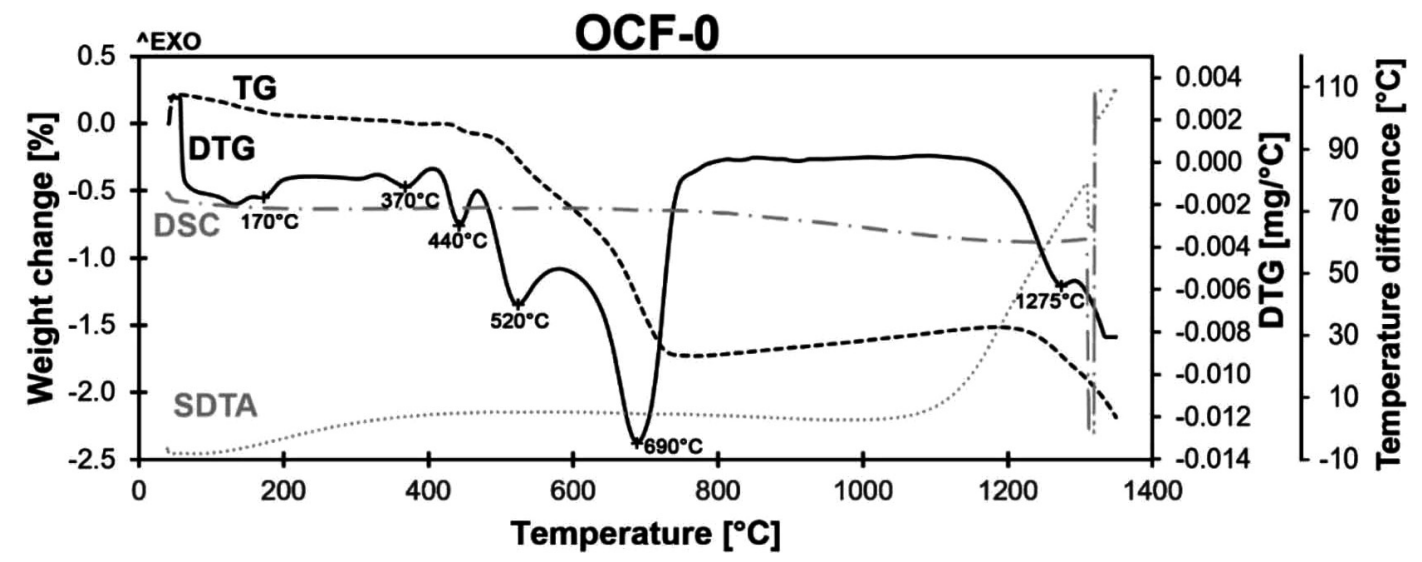

Figure 6: DTA/TG and DSC analysis of test sample OCF-0

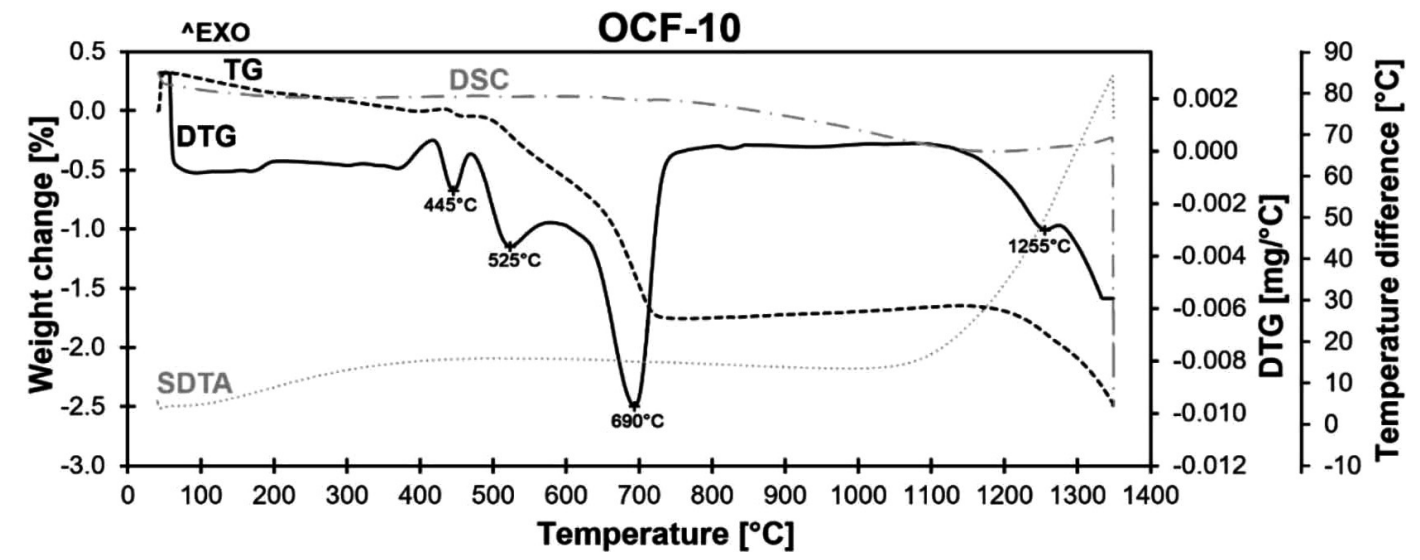

Figure 7: DTA/TG and DSC analysis of test sample OCF-10

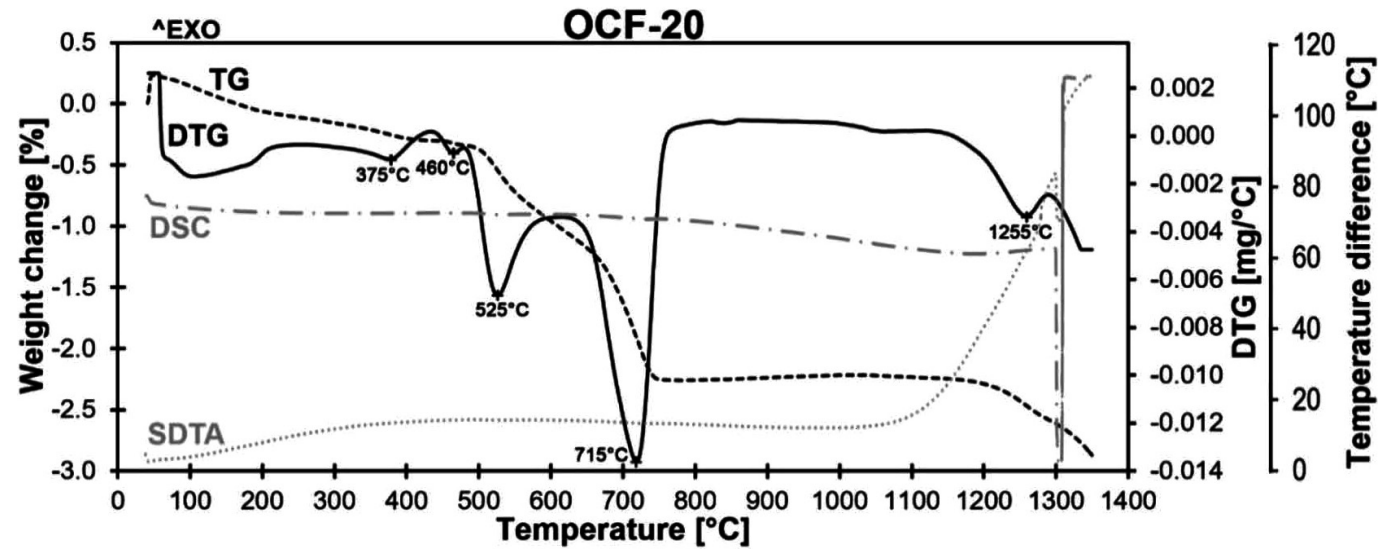

Figure 8: DTA/TG and DSC analysis of test sample OCF-20

\section{DISCUSSION}

The increased firing shrinkage (Table 3) of the mixtures with higher amounts of fly ash is due to the presence of accessory oxides $\left(\mathrm{Fe}_{2} \mathrm{O}_{3}, \mathrm{~K}_{2} \mathrm{O}, \mathrm{Na}_{2} \mathrm{O}\right.$ and $\mathrm{CaO}$ ), which promote the densification of the samples and creation of an amorphous glass phase, which can be seen as a curved background of the XRD patterns. With the increased amount of fly ash in the mixtures, the porosity and water absorption also increase while the bulk density decreases (Table 3). This phenomenon can be explained with the results of a thermodilatometric analysis (Figure 2) where, in the temperature interval of $1250-1350{ }^{\circ} \mathrm{C}$, the expansion stage of the samples with fly ash occurred, followed by the re-shrinkage stage. Y. Dong, S. Hampshire et al. ${ }^{8}$ also reported this behaviour in their work. This expansion is attributed to the formation of an amorphous phase with a lower density (around $17 \%$ ) than that of quartz. ${ }^{1-2}$ 
In the thermal analyses (Figures 6 to 8 ), the SDTA and DSC curves exhibit strongly exothermic reactions, starting at around $1100{ }^{\circ} \mathrm{C}$, indicating the oxidation of fayalite into magnetite and amorphous silica (Equation 1) in all the samples and also a simultaneous crystallization of the MA spinel from mullite and periclase (Equation 2) in the samples with fly ash. These results are also confirmed by the XRD analysis (Figure 5) and SEM with the EDX probe (Figure 4, bottom). The surplus silicon dioxide then reacts with periclase to form forsterite according to Equation (3). ${ }^{14}$

$$
3\left(2 \mathrm{FeO} \cdot \mathrm{SiO}_{2}\right)+\mathrm{O}_{2} \stackrel{1205^{\circ} \mathrm{C}}{\longrightarrow} 2 \mathrm{Fe}_{3} \mathrm{O}_{4}+3 \mathrm{SiO}_{2}
$$

fayalite + oxygen $\rightarrow$ magnetite + silicone dioxide

$$
\begin{gathered}
3 \mathrm{Al}_{2} \mathrm{O}_{3} \cdot 2 \mathrm{SiO}_{2}+3 \mathrm{MgO} \rightarrow 3 \mathrm{MgO} \cdot \mathrm{Al}_{2} \mathrm{O}_{3}+2 \mathrm{SiO}_{2} \\
\text { mullite }+ \text { periclase } \rightarrow \mathrm{MA}-\text { spinel }+ \text { silicone dioxide } \\
2 \mathrm{MgO}+\mathrm{SiO}_{2} \rightarrow 2 \mathrm{MgO} \cdot \mathrm{SiO}_{2} \\
\text { periclase }+ \text { silicon dioxide } \rightarrow \text { forsterite }
\end{gathered}
$$

With the increased amount of fly ash in the mixture, the MOR (Table 3) of the test samples is also increased due to the positive effect of MA spinel, improving the mechanical properties of the forsterite ceramics. ${ }^{14} \mathrm{MA}$ spinel is formed as small crystals of $2-4 \mu \mathrm{m}$ in diameter on the edges of large forsterite crystals or in the connecting space between the patches of forsterite crystals and the amorphous glass matrix, as seen in the SEM images of the microstructure (Figure 4). This attribute allows the test samples with MA spinel to have a higher MOR due to the interconnection between the MA spinel crystals and the forsterite matrix, which improves the microstructure.

MA spinel has a lower thermal-expansion coefficient than forsterite, leading to an improvement of the thermal-shock resistance of the mixtures with fly ash. ${ }^{5}$ The residual MOR (Table 3) characterizes the thermalshock resistance according to standard EN 993-11:2007 method B. The residual MOR of mixture OCF-0 without fly ash was, on average, $3 \%$; for mixture OCF-10 with $10 \%$ of fly ash, it was, on average, $19 \%$ and for mixture OCF-20 with $20 \%$ of fly ash, it was, on average, $25 \%$. It can be concluded that MA spinel significantly improved the thermal-shock resistance. With the increased amount of fly ash in the mixture, the thermal-shock resistance is higher due to the presence of MA spinel crystals interlocking the forsterite patches with the amorphous glass matrix (the SEM analysis) and due to a higher amount of flux oxides, promoting the creation of the amorphous glass phase and sintering of the test samples.

The thermal analyses (Figures 6 to 8 ) confirmed the results of the XRD analysis and SEM with the EDX probe. There are several endothermic peaks on the DTG (the $1^{\text {st }}$ derivation of TG) curve. The first broad peak up to $200{ }^{\circ} \mathrm{C}$ is due to the loss of adsorbed water, the next peaks at around $370{ }^{\circ} \mathrm{C}$ and $440{ }^{\circ} \mathrm{C}$ are due to the de- hydroxylation of water from serpentine. ${ }^{15,16}$ The peak at $525{ }^{\circ} \mathrm{C}$ is due to the modification from $\beta$-quartz to $\alpha$-quartz. The endothermic peak at around $690{ }^{\circ} \mathrm{C}$ is due to the decomposition of kaolinite into metakaolin and water ${ }^{1}$ and also the subsequent decomposition of serpentine. The last peak is between $1255-1275^{\circ} \mathrm{C}$ and is due to the decomposition of fayalite, which melts at $1205^{\circ} \mathrm{C}$, and an amorphous silica phase is formed. ${ }^{1-2}$

There is a strong exothermic peak on the SDTA curves (Figures 6 to 8), which starts at $1100^{\circ} \mathrm{C}$ and continues up to $1350{ }^{\circ} \mathrm{C}$. This exothermic reaction is due to the crystallization of MA spinel from mullite and periclase and also the solid-state reaction needed for the formation of forsterite. ${ }^{8}$ MA spinel was identified with the XRD analysis and the EDX probe of SEM while no traces of mullite were found.

\section{CONCLUSIONS}

Refractory forsterite ceramics were sintered at $1400{ }^{\circ} \mathrm{C}$ and $1500{ }^{\circ} \mathrm{C}$ from calcined magnesite, olivine, fly ash and kaolin. Different amounts of fly ash were used to evaluate the creation of MA spinel from aluminium and magnesium oxides and its influence and properties after firing. An XRD analysis confirmed the presence of forsterite as the major crystal phase with minor phases of periclase, magnetite, monticellite and MA spinel in the mixtures with fly ash.

Spinel formed dipyramidal crystals $(2-4 \mu \mathrm{m}$ in diameter) on the edges and in the space between large forsterite crystals in the matrix. The formation of spinel improved the modulus of rupture and thermal-shock resistance while only a minor decrease in the refractoriness and refractoriness under load occurred.

In the samples with fly ash, the expansion stage occurred in the temperature interval of $1250-1350{ }^{\circ} \mathrm{C}$, which is attributed to the creation of an amorphous silica phase. Flux oxides contained in fly ash promoted the creation of this amorphous phase. Therefore, with the increased amount of fly ash, more amorphous phase was formed and this resulted in a higher shrinkage, porosity, water absorption and a lower bulk density.

In conclusion, the addition of fly ash into the rawmaterial mixture of forsterite ceramic resulted in the creation of a small amount of MA spinel that improved the mechanical properties, microstructure and thermalshock resistance of forsterite ceramic. Simultaneously, the refractory properties were impaired only by less than $5 \%$.

\section{Acknowledgment}

This article was supported by the Internal Grant Agency of the Brno University of Technology, specific junior research No. FAST-J-19-5815, with project name: Influence of accessory oxides in raw materials on properties and synthesis of forsterite ceramics. And also 
under the Czech Science Foundation GAČR, project no. 18-02815S with project name: Elimination of Sulphur oxide emission during the firing of ceramic bodies based on fly ashes of class $C$.

\section{REFERENCES}

${ }^{1}$ P. P. Budnikov, Technology of ceramics and refractories, MIT press Ltd, Cambridge, 1964, 270-283

${ }^{2}$ W. Kingery, Introduction to ceramics, Wiley, New York, 1960, 261-284

${ }^{3}$ F. Zhao, L. Zhang, Z. Ren, J. Gao, X. Chen, X. Liu, T. Ge, A novel and green preparation of porous forsterite ceramics with excellent thermal isolation properties, Ceramics International, 45 (2019) 3, 2953-2961, doi:10.1016/j.ceramint.2018.09.296

${ }^{4}$ M. Bouhifd, D. Andrault, G. Fiquet, P. Richet, Thermal expansion of forsterite up to the melting point, Geophysical research letters, 23 (1996) 10, 1143-1146

${ }^{5}$ E. Mustafa, N. Khalil, A. Gamal, Sintering and microstructure of spinel-forsterite bodies, Ceramics International, 28 (2002) 6, 663-667, doi:10.1016/S0272-8842(02)00025-1,

${ }^{6}$ I. Ganesh, A Review on Magnesium Aluminate (MgA12O4) Spinel: Synthesis, Processing and Applications, International Materials Reviews, 58 (2013) 2, 63-112, doi:10.1179/1743280412Y. 0000000001

${ }^{7}$ R. B. Graf, F. M. Wahl, R. E. Grim, Phase transformations in silica-alumina-magnesia mixtures as examined by continuous X-ray diffraction: II. Spinel-silica compositions, American Mineralogist, 48 (1963) 1-2, 150-158

${ }^{8}$ Y. Dong, S. Hampshire, J. Zhou, Z. Ji, J. Wang, G. Meng, Sintering and characterization of fly ash-based mullite with $\mathrm{MgO}$ addition,
Journal of the European Ceramic Society, 31 (2011), 687-695, doi:10.1016/j.jeurceramsoc.2010.12.012

${ }^{9}$ M. S. Kumar, M. Vanmathi, G. Senguttuvan, R. V. Mangalaraja, G. Sakthivel, Fly Ash Constituent-Silica and Alumina Role in the Synthesis and Characterization of Cordierite Based Ceramics, Silicon, (2018), 1-13, doi:10.1007/s12633-018-0049-0

${ }^{10}$ E. M. M. Ewais, A. A. M. El-Amir, D. H. A. Besisa, M. Esmat, B. E.H. El-Anadouli, Synthesis of nanocrystalline $\mathrm{MgO} / \mathrm{MgAl} 2 \mathrm{O} 4$ spinel powders from industrial wastes, Journal of Alloys and Compounds, 691 (2017), 822-833, doi:10.1016/j.jallcom.2016. 08.279

${ }^{11}$ W. Wons, K. Rzepa, M. Reben, P. Murzyn, M. Sitarz, Z. Olejniczak, Effect of thermal processing on the structural characteristics of fly ashes, Journal of Molecular Structure, 1165 (2018), 299-304, doi:10.1016/j.molstruc.2018.04.008

${ }^{12}$ M. Nguyen, R. Sokolár, Influence of Fly Ash Addition in the Raw Mixture on Synthesis and Properties of Forsterite, Solid State Phenomena, 296 (2019), 180-185, doi:10.4028/www.scientific.net/ SSP.296.180

${ }^{13}$ M. Nguyen, R. Sokolár, Presence of magnesium-alumina spinel in forsterite ceramics and its influence during sintering and on resulting properties of fired body, IOP Conf. Ser.: Mater. Sci. Eng., 549 (2019) 012025, doi:10.1088/1757-899X/549/1/012025

${ }^{14}$ R. Michel, M. R. Ammar, P. Simon, E. de Bilbao, J. Poirier, Behaviour of olivine refractories at high temperature: agglomeration in a fluidized bed reactor, Refractories Worldforum 6 (2014), 95-98

${ }^{15}$ D. Hršak, J. Malina, A. B. Hadžipašić, The decomposition of serpentine by thermal treatment, Materiali in Tehnologije, 39 (2005) 6, 225-227

${ }^{16}$ A. F. Gualtieri, M. Gemmi, M. Dapiaggi, Phase transformations and reaction kinetics during the temperature-induced oxidation of natural olivine, American Mineralogist, 88 (2003) 10, 1560-1574, doi:10.2138/am-2003-1019 